\title{
Effect Of Relational Capital On The Performance Of Small - Medium Enterprises In North Central Nigeria
}

\author{
UDOH, Francis Sylvanus *, BUKOYE, Josiah Ayoola *, YAHAYA, Kabiru Maigari ** \\ * Department of Business Administration, Nasarawa State University Keffi \\ DOI: 10.29322/IJSRP.11.09.2021.p11748 \\ http://dx.doi.org/10.29322/IJSRP.11.09.2021.p11748
}

\begin{abstract}
Business management has traditionally been concerned with value of the organization, valuing processes and the performance of the organization. Hence, relational capital emerges as a result of well-thought actions. It depends on strategic decisions and organized actions. Creation and development of relational capital is considerably brought down to creation of conditions, which would enable to initiate, shape, develop and maintain relationships between members of a given organization, and between the organization and subjects from its surrounding. The study examines the effect of Relational Capital (RC) on the performance of SMEs in North central Nigeria. Despite the fact that the significance of RC is always expanding, numerous SMEs confront issues with its administration, for the most part because of estimation challenges on external and internal relation capital. The time frame for this study was five years from 2015 to 2019 . The research design adopted for the study was the survey design. The population of small and medium enterprises (SMEs) in this study was 9586 in North Central Nigeria. The study used Taro Yamane's formula to determine the sample size of 384 owners of SMEs in North Central, Nigeria. The method of data collection used by this study was a questionnaire that was administered to the respondents. The statistical tools used is multiple regression. The findings revealed that external and internal relation capital has a positive and significant effect of on the performance of SMEs in North Central Nigeria. Other findings revealed that held resources has insignificant effect on the performance of SMEs in North Central Nigeria. The study therefore recommends that SMEs should continue to manage and nurture their relational capital in the North Central zone of Nigeria, as it appears to be more successful in increasing their performances. However, only one of the elements that comprised relational capital revealed an insignificant effect on SMEs performance, which is held resources. Therefore, SMEs should try and minimize these held resources so as to improve their relationship with suppliers.
\end{abstract}

Index Terms- External and Internal Relational Capital, Performance and SMEs

\section{INTRODUCTION}

$I^{n}$ today's business world, it is generally accepted that the main components of intellectual capital can be structured into three dimensions: human capital, structural capital and relational capital (Martin de Castro et al. 2011). The relational capital is based on the consideration that companies are not isolated systems. On the contrary, they are actively and permanently connected to multiple external and internal entities. All valuable relationships of this kind, with customers, suppliers and other relevant stakeholders, represent relational capital (Roos, Bainbridge \& Jacobsen. 2001). Also, an effective operation of an organisation, of adaptations abilities is the skill of developing and maintaining relationships with various entities. These relationships exert certain influence on existence and the level of organisational development. The relational capital depends on external and internal factors. Its sources are exo and endogenic relational resources, as well as other placed outside and inside an organization. Furthermore, model, held resources and transactional costs are key to a better relational capital. (Chomiak-Orsa, 2013)

Small and Medium Scale Enterprises (SMEs) have been widely perceived all over the world as the backbone of a nation's economy and a key wellspring of economic development in both developed and emerging economies. It is labour and capital demanding business adventure, making individuals independent through wealth creation, employment generation, poverty alleviation, and food security (Dundon \& Wilkinson, 2018). Nigerian government has acknowledged the significance of SMEs through its institutions by creating job opportunities to its citizens (Gumel, 2017).

In the present information-based economy, numerous scientists guarantee that individuals are our most prominent resource. As expressed by Fitz-enz (2000) individuals are the most intense factor in esteem formation of each company. Subsequently, to build up an upper hand, it is imperative that organizations mostly SMEs genuinely use on the workforce as an aggressive weapon to complete the organisation's goals through effective relationship.

In line with the above, the world is moving quickly from a production-based economy to a knowledge-based economy (Huang \& Wu, 2010) and knowledge storage and application are the basis of economic growth and accumulated capital (Hsu \& Fang, 2009). Wong and Aspinwall (2004) argued that SMEs' close proximity to their customers, enables them to acquire knowledge in a more direct and faster flow, compared to larger firms. In the globalized and knowledge-based economy, SMEs need to develop, manage and monitor their soft assets through relational capital (RC) to enhance their growth and competitiveness. It is on the foregoing background that this study sets out to examine the effect of relational capital on the performance of SMEs in North Central Nigeria.

It is a well-known fact that, across the board, SMEs are faced by constant threat of failure and most of them never grow into large enterprises (RoK, 2005). It is indicated that SMEs lack 
adequate resources, adequate management skills and successful marketing strategies. Despite the fact that the significance of Relational Capital (RC) is always expanding, numerous SMEs confront issues with its administration, for the most part because of estimation challenges on external and internal relation capital.

The general objective of this study was to examine the effect of relational capital on the performance of small and medium enterprises in North Central Nigeria. Other specific objectives are: To evaluate the effect of external relational capital on the performance of SMEs in North Central Nigeria and to determine the effect of internal relational capital on the performance of SMEs in North Central Nigeria.

In line with the objective of the study the following hypotheses are stated in a null form, they are:

Ho1: External Relational Capital has no significant effect on the performance of SMEs in North Central Nigeria

Ho2: Internal Relational Capital has no significant effect on the performance of SMEs in North Central Nigeria

Previous studies such as Datta and De (2017); assessed the impact of relational capital components on the performance of bell-metal clustered firms in Dharmada region of Nadia district in the State of West Bengal in India and found out that the overall index of relational capital is found strongly associated with profitability performance. Also, Ogundipe (2012); examined the effect of relational capital components on firms' performance of selected Small-Scale Enterprises Clusters in Southwestern geopolitical zone of Nigeria. Using five-point Likert's scale. He found that the Relationship with suppliers, customers and internal networks among the employees were positively and significantly related to and predictor of the clusters' firm performance. However, none of these studies used the North Central of Nigeria and none used efficiency as a measure for performance. Therefore, this study fills the research gap by looking at relational capital and performance of SMEs in North Central Nigeria.

\section{Concept of Relational Capital}

Business management has traditionally been concerned with value of the organization, valuing processes and the performance of the organization. In the late 1990s an approach of intellectual capital was born to address the exploring, understanding and measuring the intangible nature of innovation and value creation (Sveiby 1997, Edvinsson and Malone 1997). It is oftentimes seen as one entity, though it also seen to include components of structural capital, human capital and relational capital.

Relational capital is explained as value that is created and maintained by having, nurturing and managing good relationships. Relational capital is framed as the totality of relations between a firm and its main stakeholders and is operationalized through image, customer loyalty, customer satisfaction, link with suppliers, commercial power, negotiating capacity with financial entities, environmental activities, etc. (Bronzetti, Mazzolta, Puntillo, Silvestri, \& Veltri 2011). Relational capital has many definitions. It is generally explained with words such as alliances, exchange, resource, social network processes, relationships, relations, customers, suppliers, employees, and co-operation, internal, and external in the arena of management studies
Furthermore, literature of the subject assumes that it is a component of the intellectual capital. The relation capital refers to relational resources emerging from the potential gathered within an organization. Relational resources are characterized with the fact that they are present on the edge between an enterprise and the surrounding, and their essence is the ability to establish and use the relationships on the basis of cooperation between the entities. Therefore, the relational capital poses a result of the ability to create and build permanent relations. A condition is mutual trust, openness, transparent, social bonds and common values of the entities. (Heide \& John, 1992).

The relational capital is not present independently, but in relation to human (capital of managers, employees) and structural capital, as a component of the intellectual capital. The relational capital emerges as a result of well- thought actions. it depends on strategic decisions and organized actions. Creation and development of relational capital is considerably brought down to creation of conditions, which would enable to initiate, shape, develop and maintain relationships between members of a given organization, and between the organization and subjects from its surrounding. (Heide \& John, 1992).

The relational capital depends on external and internal factors. Its sources are exogenic and endogenic relational resources, as well as other placed outside and inside an organization. Furthermore, the relational capital is influenced by external and internal conditions. Within the scope of external conditions, significance is ascribed to the business model, held resources and transactional costs. The process of relational capital development adopts formal and informal contacts between employees and the interested parties, as well as factors existing within the organizational environment. Through proper expenditures on development of the external and internal relationships networks there is a possibility to access adequate resources that support shaping of the commonality of interests. (Heide \& John, 1992).

Summing up the above deliberations, it may be notices that the relational capital often refers to the relational resources, which emerge from the potential gathered in the organization in the course of creation and development of permanent relationships by the organization, based on relational standards. They are defined as a series of partially overlapping and cohesive principles of conduct (Heide \& John, 1992).

\section{Concept of Small and Medium Enterprises}

The definition of SMEs varies from country to country, region to region and from agencies to agencies in today's global world. The Nigerian concepts of SMEs are somewhat divergent but the Central Bank of Nigeria agrees with the Small and Medium Industries and Equity Investment Scheme (SMIEIS) in their definition of an SME as any enterprise with a maximum asset base less than N200 million (equivalent of about $\$ 1.43$ million) excluding land and working capital, and with the number of staff employed not less than 10 (otherwise will be a cottage or microenterprise) and not more than 300 (Udechukwu, 2003)

In Nigeria, the Central Bank of Nigeria in its monetary policies circular No. 22 of 1988 well-defined SMEs as enterprises which have a yearly turnover not surpassing Five Hundred Thousand Naira (N500,000). Mekwunye (2018) asserts that SMEs are non-subsidiary, independent firms/organizations which utilize 
smaller number of employees, and this number changes crosswise over nations. SMEs are organizations which can best be portrayed through their capital, degree and cost of undertakings, yearly turnover, financial capabilities and number of workers amongst other things.

SMEs as characterized by the National Council of Industries allude to business enterprises whose complete expenses barring land is not in excess of Two Hundred Million Naira (N200,000,000.00) only. For lucidity, the National Policy on Micro Small and Medium Enterprises (MSMEs) espouses a classification based on twofold standards: Employment and Assets (excluding land and buildings), as follows:

Table 1: Classification Approved by National Policy on MSMEs

\begin{tabular}{|l|l|l|l|}
\hline S/N & SIZE CATEGORY & EMPLOYMENT & $\begin{array}{l}\text { ASSETS (N million) (excluding } \\
\text { land and buildings) }\end{array}$ \\
\hline 1 & Micro Enterprises & Less than 10 & Less than 5 \\
\hline 2 & Small Enterprises & $10-49$ & $5-$ less than 50 \\
\hline 3 & Medium Enterprises & $50-199$ & $50-$ less than 500 \\
\hline
\end{tabular}

\section{Source: National Policy on MSMEs 2017}

\section{Concept of Performance}

The term performance is a controversial issue in finance largely because of its multidimensional meanings Mihaela (2012). It can be defined as outcome-based financial indicators that are assumed to reflect the fulfillment of the economic goals of the firm. The performance level of most of these firms has been most unsatisfactory, as the problems of delay in delivery of services and high cost of service delivery has become a norm rather than an exception. In some other cases where the cost and time are within acceptable limits, the issue of customer satisfaction has often not been met simply due to the delivery of sub-standard outputs Oforegbunam and Okorafor (2010)

Performance is understood as achievement of the organization in relation with its set goals. It includes outcomes achieved, or accomplished through contribution of individuals or teams to the organizations' strategic goals. The term performance encompasses economic as well as behavioural outcomes. Brumbach (2015) views performance more comprehensively by encompassing both behaviours and results. He is of the view that behaviours as outcomes in their own right, which can be judged apart from results. Performance is an impact. The roles of any manage can be seen in three parts: Being, Doing and Relating.

It is the process of identifying the financial strengths and weaknesses of the firm by properly establishing relationship between the items of the balance sheet and the profit and loss account and it relates to the motive of maximizing profit both to the shareholders and on assets (Ishaya et al, 2014) while the operational performance concerns with growth and expansions in relations to sales and market value Zeitun et al (2007).

The concept of SMEs performance is generally centred on either efficiency or effectiveness. Since business enterprises need to eventually be profitable to survive, financial efficiency in several forms (e.g., gross margins, net margins, ROI, relative profitability) is typically used as an ultimate outcome when the performance is included in research. The outcome particularly utilizes self-reports on financial and non-financial measure, and each measure is one of the most commonly used definitions of firm performance in the research. The financial measure is focused on overall profit level, profit margin, and return on investment in finance; whereas the non-financial measure is related to customer and employee satisfaction.

\section{Empirical Review}

Datta and De (2017) assess the impact of relational capital components on the performance of bell-metal clustered firms in Dharmada region of Nadia district in the State of West Bengal in India. The issue of relational capital has been considered in relation to the notion of intangible asset. Eight components of relational capital indicators were considered and they were combined into a single overall index by using principal component method. A study was conducted on a sample of sixty firms in the cluster. Cronbach's alpha has been used to assess the reliability or internal consistency of the set of individual relational capital indicators. The overall index of relational capital is found strongly associated with profitability performance. The overall regression of profitability figures on individual relational capital indicators has been observed to be significant and some of the indicators are also found to significantly influence firm performance level. The analysis identifies and provides suggestion regarding upgrading and maintaining relational capital components in which the firms may have some advantage.

Pedro, Ricardo and Carlos (2013) discusses the influence of relational capital on product innovation performance at innovative small and medium enterprises (SMEs). Building upon the intellectual capital and new product development perspectives, an empirical research was conducted, using a questionnaire administered to a network of Portuguese innovative SMEs. The findings suggest that relational capital does have a positive effect on product innovation performance. In particular, "Vertical relationships" emerges as the main relational capital element significantly affecting product innovation at the innovative SMEs 
level. The existence and proactive management of relationships with customers and suppliers emerge as critical factors to product innovation success.

Ogundipe (2012) examines the effect of relational capital components on firms' performance of selected Small-Scale Enterprises Clusters in Southwestern geo-political zone of Nigeria. Nigeria. It examines the business aspect of relational capital in Nigeria context. The units of study were the firms within the cluster, and two clusters, Abeokuta and Osogbo located in Ogun and Osun State respectively in South Western Nigeria. The data for the measures of the variables are collected through questionnaire adapted from Tumwine (2010) survey using fivepoint Likert's scale. 94 survey instruments were distributed while 80 were returned and found useful for the analysis. A correlation matrix and multiple regression models were used to test the hypotheses advanced. The Relationship with suppliers, customers and internal networks among the employees were found to be positively and significantly related to and predictor of the clusters' firm performance.

\section{Theoretical Framework}

\section{Product Innovation Theory}

The theory found adequate for this study is the product innovation theory. One of the most famous creators of new products, Thomas Edison, is mentioned by Hargadon and Sutton (1997) as a good example of how developing network connections across industries can benefit product innovation. This theory illustrates the fact that continuous innovation is often related to occupying a "structural hole", that is, the gap in the flow of information between subgroups in a larger network (Hargadon and Sutton 1997). Knowledge is often shared imperfectly through time, people, organizations and industries. The ideas that come up in a group could solve other groups' problems, but that can only happen if there are links that can go through the existing frontiers between solutions and problems. When those connections take place, existing ideas can appear new and creative, as they change shape and are combined with other ideas to solve new problems. We thus argue that high levels of relational capital at the firm level (through a clear orientation to develop links with multiple external knowledge sources) strengthen the firm's ability to absorb and transform new knowledge, and thus its product innovation potential. In fact, some authors (eg. Cohen \& Levinthal 1990) state that the ability of a firm to recognise the value of new, external information, assimilate it, and apply it to commercial ends (that is, the firm's absorptive capacity) represents a learning process that is critical to its innovative capabilities.

\section{Methodology}

The study adopted the survey research design and this is because the information or data needed for the study required the use of structured questionnaire that was administered to the respondents who are comprised of staff, owners or MDs of the SMEs businesses in the North Central zone of Nigeria. Also, the population of the study consist of all the registered SMEs in the North Central of Nigeria. According to Small and Medium Enterprises Development Agency Nigeria (SMEDAN) and National Bureau of Statistics (NBS) (2013) collaborative survey, there are 9586 registered SMEs businesses in North Central, Nigeria. The population of the SMEs in the North Central is listed in the table 1.1:

Table 1.1 Selected SMEs in North Central, Nigeria

\begin{tabular}{|l|l|l|l|}
\hline STATE & SMALL & MEDIUM & TOTAL \\
\hline ABUJA (FCT) & 2244 & 446 & 2690 \\
\hline BENUE & 1146 & 22 & 1168 \\
\hline KOGI & 827 & 17 & 844 \\
\hline KWARA & 164 & 62 & 226 \\
\hline NASARAWA & 1098 & 22 & 1120 \\
\hline NIGER & 1258 & 100 & 1358 \\
\hline PLATEAU & 2070 & 110 & 2180 \\
\hline TOTAL & 8807 & 779 & 9586 \\
\hline
\end{tabular}

\section{Source: SMEDAN \& NBS Survey (2017)}

Thus, the population of SMEs in this study was 9586 in North Central Nigeria and was reduced using the Taro Yamane (1967) formula as stated below:

$\mathrm{n}=\mathrm{N} / 1+\mathrm{N}(\mathrm{e})^{2}$
Where $\mathrm{N}$ is the population size $\mathrm{e}$ is the margin error (assume 5\%)

$1=$ constant

$\mathrm{e}=0.05$

$\mathrm{n}=9586 / 1+9586(0.05)^{2}$ 
$\mathrm{n}=9586 / 1+9586(0.0025)$

$\mathrm{n}=9586 / 1+23.965$

$\mathrm{n}=9586 / 24.965$

$\mathrm{n}=383.9$ or 384 sampling technique in selecting the 384 from 9586 SMEs in North Central, Nigeria. The researcher considered a purposive sampling technique by using proportional method in selecting sample in each of the states of the North Central Zone and these are:

Therefore, the sample size of the study was 384 of the SMEs in North Central Nigeria. Furthermore, the study used a purposive

Table 1.2 Proportion of Small and Medium Enterprises in North Central, Nigeria

\begin{tabular}{|l|l|l|l|}
\hline STATE & Population & Proportion & Sample \\
\hline ABUJA (FCT) & 2690 & $2690 \times 384 / 9586$ & 108 \\
\hline BENUE & 1168 & $1168 \times 384 / 9586$ & 47 \\
\hline KOGI & 844 & $844 \times 384 / 9586$ & 34 \\
\hline KWARA & 226 & $226 \times 384 / 9586$ & 9 \\
\hline NASARAWA & 1120 & $1120 \times 384 / 9586$ & 45 \\
\hline NIGER & 1358 & $1358 \times 384 / 9586$ & 54 \\
\hline PLATEAU & 2180 & $2180 \times 384 / 9586$ & 87 \\
\hline TOTAL & 9586 & - & 384 \\
\hline
\end{tabular}

\section{Source: Researchers Computation (2021)}

From table 1.2, the sample size for each of the states in the North central zone was to apportion copies of questionnaires each as it appears on the proportion index. For example, FCT has the highest number of registered SMEs population in the North Central of 2690 and after the proportion applied, it received a total of 108 copies of questionnaires that was administered to the SMEs operators in FCT. The same was applied to other six states in the North Central zone. Furthermore, the method of data collection was questionnaire administered to the respondents. The reason for using primary source of data was that, it is crucial in presenting a study of this nature and other research data that is based on original data produced by the respondents that are actually involved in the subject area of research. It was designed in a five (5) point Likert type scale questionnaire to collect data from the respondents. The question provides information on the effect of relational capital on the performance of SMEs in North Central Nigeria. However, copies of questionnaire were administered to the respondents using simple random sampling method.

Finally, the study used the Ordinary Least Square (OLS) multiple regression method to determine the effect of the independent variable on the dependent variable. The OLS method is one of the most popular and widely used methods for regression analysis. The statistical test of parameter estimates shall be conducted using their standard error, t-test, F-test, $\mathrm{R}$, and $\mathrm{R}^{2}$. The economic criteria shall show whether the coefficients of the variable conform to the economic a priori expectation, while the statistical criteria test was used to assess the significance of the overall regression.

$\mathrm{Y}=\alpha+\beta_{\mathrm{I}} \mathrm{X}$

Where $y=$ dependent variable, $\alpha=$ intercept, $\beta_{\mathrm{I}}$ is coefficient and $\mathrm{X}$ is the independent variable. However, the above model is expressed as:

$\mathrm{PSME}=\alpha+\beta_{\mathrm{I}} \mathrm{BM}+\beta_{2} \mathrm{HR}+\beta_{3} \mathrm{TC}+\mu \ldots$ equation 1

PSME $=\alpha+\beta_{1} \mathrm{CBE}+\beta_{2} \mathrm{CWS}+\beta_{3} \mathrm{OR}+\mu$...equation 2

Where: PSME = Performance of SMEs ( measured as efficiency) , $\beta=$ Coefficient, $\alpha=$ Intercept, $\mu=$ Error terms, $\mathrm{BM}=$ Business Model, HR = Held Resources, TC $=$ Transactional Cost, $\mathrm{CBE}=$ Contact between Employees, CWS = Contact with Suppliers and $\mathrm{OR}=$ Organisational Environment 
Data Analysis and Result

Table 3: Assessment of Transactional Cost Small - Medium Enterprises in North Central Nigeria

\begin{tabular}{|l|l|l|l|l|l|}
\hline Items & $\mathbf{5}$ & $\mathbf{4}$ & $\mathbf{3}$ & $\mathbf{2}$ & $\mathbf{1}$ \\
\hline $\begin{array}{l}\text { Small and medium scale enterprises in North } \\
\text { Central Nigeria frequently conducted } \\
\text { economic trade }\end{array}$ & $102(26.56)$ & $122(31.77)$ & $53(13.80)$ & $33(8.59)$ & $74(19.27)$ \\
\hline $\begin{array}{l}\text { There is effective bargaining cost among } \\
\text { small and medium scale enterprises in North } \\
\text { Central Nigeria }\end{array}$ & $112(29.17)$ & $98(25.52)$ & $49(12.78)$ & $34(8.85)$ & $91(23.70)$ \\
\hline $\begin{array}{l}\text { Small and medium scale enterprises in North } \\
\text { Central Nigeria usually incur transfer cost } \\
\text { for the purpose of growing the business }\end{array}$ & $121(31.51)$ & $111(28.91)$ & $44(11.46)$ & $31(8.07)$ & $77(20.05)$ \\
\hline
\end{tabular}

\section{Source: Survey, 2021}

From the above table, it was discovered that majority of the respondents strongly agreed $(26.55 \%)$ and agreed $(31.77 \%)$ to the statement that SMEs in North Central Nigeria frequently conducted economic trade. $8.59 \%$ strongly disagreed and $19.27 \%$ disagreed with the said statement while only $13.80 \%$ were undecided.

It was also observed that the majority of the respondents, $29.17 \%$ and $25.52 \%$ strongly agreed and agreed respectively that there is effective bargaining cost among SMEs in North Central Nigeria. $8.85 \%$ and $23.70 \%$ strongly disagreed and disagreed respectively, while only $12.78 \%$ were undecided.

From the table also, the majority of the respondents $31.51 \%$ and $28.91 \%$ strongly agreed and agreed respectively that SMEs in North Central Nigeria usually incur transfer cost for the purpose of growing the business. $8.07 \%$ and $20.05 \%$ strongly disagreed and disagreed respectively, while $11.46 \%$ were undecided.

Table 4: Assessment of Held Resources in Small - Medium Enterprises in North Central Nigeria

\begin{tabular}{|l|l|l|l|l|l|}
\hline Items & $\mathbf{5}$ & $\mathbf{4}$ & $\mathbf{3}$ & $\mathbf{2}$ & $\mathbf{1}$ \\
\hline $\begin{array}{l}\text { Small and medium scale enterprises in } \\
\text { North Central Nigeria frequently held } \\
\text { finance in order to invest in future }\end{array}$ & $114(29.69)$ & $110(28.65)$ & $54(14.06)$ & $49(12.76)$ & $57(14.84)$ \\
\hline $\begin{array}{l}\text { Small and medium scale enterprises in } \\
\text { North Central Nigeria usually held } \\
\text { material resources for further production }\end{array}$ & $122(31.77)$ & $119(30.99)$ & $59(15.36)$ & $50(13.02)$ & $34(8.85)$ \\
\hline $\begin{array}{l}\text { Small and medium scale enterprises in } \\
\text { North Central Nigeria usually held new } \\
\text { equipment to produce latest product }\end{array}$ & $118(30.73)$ & $123(32.03)$ & $49(12.76)$ & $48(12.50)$ & $46(11.98)$ \\
\hline
\end{tabular}

\section{Source: Survey, 2021}

From the above table, it was discovered that majority of the respondents strongly agreed $(29.69 \%)$ and agreed $(28.65 \%)$ to the statement that SMEs in North Central Nigeria frequently held finance in order to invest in future. $12.76 \%$ strongly disagreed and $14.84 \%$ disagreed with the said statement while only $14.06 \%$ were undecided.

It was also observed that the majority of the respondents, $31.77 \%$ and $30.99 \%$ strongly agreed and agreed respectively that SMEs in North Central Nigeria usually held material resources for further production. $13.02 \%$ and $8.85 \%$ strongly disagreed and disagreed respectively, while only $15.36 \%$ were undecided.

From the table also, the majority of the respondents $30.73 \%$ and $32.03 \%$ strongly agreed and agreed respectively that SMEs in North Central Nigeria usually held new equipment to produce latest product. $12.50 \%$ and $11.98 \%$ strongly disagreed and disagreed respectively, while $12.76 \%$ were undecided. 
Table 5: Assessment of Contact with employees in Small - Medium Enterprises in North Central Nigeria

\begin{tabular}{|l|l|l|l|l|l|}
\hline Items & $\mathbf{5}$ & $\mathbf{4}$ & $\mathbf{3}$ & $\mathbf{2}$ & $\mathbf{1}$ \\
\hline $\begin{array}{l}\text { Small and medium scale enterprises in North } \\
\text { Central Nigeria frequently communicate } \\
\text { their product ideas to employees }\end{array}$ & $144(37.50)$ & $112(29.17)$ & $44(11.46)$ & $40(10.42)$ & $44(11.46)$ \\
\hline $\begin{array}{l}\text { Small and medium scale enterprises in North } \\
\text { Central Nigeria frequently trust their } \\
\text { employees }\end{array}$ & $121(31.51)$ & $111(28.91)$ & $52(13.54)$ & $49(12.76)$ & $51(13.26)$ \\
\hline $\begin{array}{l}\text { Small and medium scale enterprises in North } \\
\text { Central Nigeria frequently build employees } \\
\text { moral }\end{array}$ & $119(30.99)$ & $121(31.51)$ & $41(10.68)$ & $59(15.36)$ & $44(11.46)$ \\
\hline
\end{tabular}

Source: Survey, 2021

From the above table, it was discovered that majority of the respondents strongly agreed $(37.50 \%)$ and agreed $(29.17 \%)$ to the statement that SMEs in North Central Nigeria frequently communicate their product ideas to employees. $10.42 \%$ strongly disagreed and $11.46 \%$ disagreed with the said statement while only $11.46 \%$ were undecided.

It was also observed that the majority of the respondents, $31.51 \%$ and $28.91 \%$ strongly agreed and agreed respectively that SMEs in North Central Nigeria frequently trust their employees.
$12.76 \%$ and $13.26 \%$ strongly disagreed and disagreed respectively, while only $13.54 \%$ were undecided.

From the table also, the majority of the respondents $30.99 \%$ and $31.51 \%$ strongly agreed and agreed respectively that SMEs in North Central Nigeria frequently build employees moral. 15.36\% and $11.46 \%$ strongly disagreed and disagreed respectively, while $10.68 \%$ were undecided.

Table 6: Assessment of Business Model in Small - Medium Enterprises in North Central Nigeria

\begin{tabular}{|l|l|l|l|l|l|}
\hline Items & $\mathbf{5}$ & $\mathbf{4}$ & $\mathbf{3}$ & $\mathbf{2}$ & $\mathbf{1}$ \\
\hline $\begin{array}{l}\text { Business model adopted by small and } \\
\text { medium scale enterprises in North } \\
\text { Central Nigeria frequently increase } \\
\text { profitability in the organizations }\end{array}$ & $133(34.64)$ & $122(31.77)$ & $41(10.68)$ & $39(10.16)$ & $49(12.76)$ \\
\hline $\begin{array}{l}\text { Small and medium scale enterprises in } \\
\text { North Central Nigeria frequently apply } \\
\text { business model to increase the target } \\
\text { market }\end{array}$ & $122(31.77)$ & $119(30.99)$ & $59(15.36)$ & $44(11.45)$ & $40(10.42)$ \\
\hline $\begin{array}{l}\text { Small and medium scale enterprises in } \\
\text { North Central Nigeria frequently used } \\
\text { business model to reduce expenses }\end{array}$ & $118(30.73)$ & $129(33.59)$ & $49(12.76)$ & $50(13.02)$ & $38(9.90)$ \\
\hline
\end{tabular}

Source: Survey, 2021

From the above table, it was discovered that majority of the respondents strongly agreed $(34.64 \%)$ and agreed $(31.77 \%)$ to the statement that business model adopted by SMEs in North Central Nigeria frequently increase profitability in the organizations. $10.16 \%$ strongly disagreed and $12.76 \%$ disagreed with the said statement while only $10.68 \%$ were undecided.

It was also observed that the majority of the respondents, $31.77 \%$ and $30.99 \%$ strongly agreed and agreed respectively that SMEs in North Central Nigeria frequently apply business model to increase the target market. $11.45 \%$ and $10.42 \%$ strongly disagreed and disagreed respectively, while only $15.33 \%$ were undecided.
From the table also, the majority of the respondents $30.72 \%$ and $33.59 \%$ strongly agreed and agreed respectively that SMEs in North Central Nigeria frequently used business model to reduce expenses. $13.02 \%$ and $9.90 \%$ strongly disagreed and disagreed respectively, while $12.76 \%$ were undecided. 
Table 7: Assessment of Contact with Suppliers in Small - Medium Enterprises in North Central Nigeria

\begin{tabular}{|l|l|l|l|l|l|}
\hline Items & $\mathbf{5}$ & $\mathbf{4}$ & $\mathbf{3}$ & $\mathbf{2}$ & $\mathbf{1}$ \\
\hline $\begin{array}{l}\text { small and medium scale enterprises in North } \\
\text { Central Nigeria frequently create interpersonal } \\
\text { relationship with suppliers }\end{array}$ & $123(32.03)$ & $129(33.59)$ & $49(12.76)$ & $59(15.36)$ & $24(6.25)$ \\
\hline $\begin{array}{l}\text { Small and medium scale enterprises in North } \\
\text { Central Nigeria usually call suppliers on } \\
\text { business discussion }\end{array}$ & $112(29.17)$ & $122(31.77)$ & $69(17.97)$ & $41(10.68)$ & $40(10.42)$ \\
\hline $\begin{array}{l}\text { Small and medium scale enterprises in North } \\
\text { Central Nigeria frequently email suppliers on } \\
\text { new innovation }\end{array}$ & $119(30.99)$ & $130(33.85)$ & $51(13.28)$ & $50(13.02)$ & $34(8.85)$ \\
\hline
\end{tabular}

Source: Survey, 2021

From the above table, it was discovered that majority of the respondents strongly agreed (32.03\%) and agreed (33.59\%) to the statement that SMEs in North Central Nigeria frequently create interpersonal relationship with suppliers. $15.36 \%$ strongly disagreed and $6.25 \%$ disagreed with the said statement while only $12.76 \%$ were undecided. It was also observed that the majority of the respondents, $29.11 \%$ and $31.77 \%$ strongly agreed and agreed respectively that small and medium scale enterprises in North Central Nigeria usually call suppliers on business discussion.
$10.68 \%$ and $10.42 \%$ strongly disagreed and disagreed respectively, while only $17.97 \%$ were undecided.

From the table also, the majority of the respondents $30.99 \%$ and $33.85 \%$ strongly agreed and agreed respectively that SMEs in North Central Nigeria frequently email suppliers on new innovation. $13.02 \%$ and $8.85 \%$ strongly disagreed and disagreed respectively, while $13.28 \%$ were undecided.

Table 8: Assessment of Organizational Environment in Small - Medium Enterprises in North

\section{Central Nigeria}

\begin{tabular}{|l|l|l|l|l|l|}
\hline Items & $\mathbf{5}$ & $\mathbf{4}$ & $\mathbf{3}$ & $\mathbf{2}$ & $\mathbf{1}$ \\
\hline $\begin{array}{l}\text { small and medium scale enterprises in North } \\
\text { Central Nigeria frequently faced with new } \\
\text { competitors }\end{array}$ & $129(33.59)$ & $118(30.73)$ & $60(15.63)$ & $50(13.02)$ & $27(7.03)$ \\
\hline $\begin{array}{l}\text { Small and medium scale enterprises in North } \\
\text { Central Nigeria usually faced with new } \\
\text { technology }\end{array}$ & $111(28.91)$ & $129(33.59)$ & $61(15.89)$ & $45(11.72)$ & $38(9.89)$ \\
\hline $\begin{array}{l}\text { Small and medium scale enterprises in North } \\
\text { Central Nigeria frequently operates in new } \\
\text { market }\end{array}$ & $120(31.25)$ & $131(34.11)$ & $50(13.02)$ & $61(15.89)$ & $22(5.73)$ \\
\hline
\end{tabular}

Source: Survey, 2021

From the above table, it was discovered that majority of the respondents strongly agreed (33.59\%) and agreed (30.73\%) to the statement that SMEs in North Central Nigeria frequently faced with new competitors. $13.02 \%$ strongly disagreed and $7.03 \%$ disagreed with the said statement while only $12.76 \%$ were undecided.

It was also observed that the majority of the respondents, $28.91 \%$ and $33.59 \%$ strongly agreed and agreed respectively that
SMEs in North Central Nigeria usually faced with new technology. $11.72 \%$ and $9.89 \%$ strongly disagreed and disagreed respectively, while only $15.89 \%$ were undecided.

From the table also, the majority of the respondents $31.25 \%$ and $34.11 \%$ strongly agreed and agreed respectively that SMEs in North Central Nigeria frequently operated in new market. 15.89\% and $5.73 \%$ strongly disagreed and disagreed respectively, while $13.02 \%$ were undecided. 
Table 9: Assessment of Efficiency in Small - Medium Enterprises in North Central Nigeria

\begin{tabular}{|l|l|l|l|l|l|}
\hline Items & $\mathbf{5}$ & $\mathbf{4}$ & $\mathbf{3}$ & $\mathbf{2}$ & $\mathbf{1}$ \\
\hline $\begin{array}{l}\text { small and medium scale enterprises in North } \\
\text { Central Nigeria frequently utilize their input to } \\
\text { increase production }\end{array}$ & $112(29.17)$ & $98(25.52)$ & $49(12.78)$ & $34(8.85)$ & $91(23.70)$ \\
\hline $\begin{array}{l}\text { Small and medium scale enterprises in North } \\
\text { Central Nigeria always realised effective } \\
\text { output in production }\end{array}$ & $118(30.73)$ & $129(33.59)$ & $49(12.76)$ & $50(13.02)$ & $38(9.90)$ \\
\hline $\begin{array}{l}\text { Small and medium scale enterprises in North } \\
\text { Central Nigeria frequently have a good quality } \\
\text { product and increase the quantity of products }\end{array}$ & $111(28.91)$ & $129(33.59)$ & $61(15.89)$ & $45(11.72)$ & $38(9.90)$ \\
\hline
\end{tabular}

Source: Survey, 2021

From the above table, it was discovered that majority of the respondents strongly agreed $(29.17 \%)$ and agreed $(25.25 \%)$ to the statement that SMEs in North Central Nigeria frequently utilize their input to increase production. $8.85 \%$ strongly disagreed and $23.70 \%$ disagreed with the said statement while only $12.78 \%$ were undecided.

It was also observed that the majority of the respondents, $30.73 \%$ and $33.59 \%$ strongly agreed and agreed respectively that
SMEs in North Central Nigeria always realised effective output in production. $13.02 \%$ and $9.90 \%$ strongly disagreed and disagreed respectively, while only $12.76 \%$ were undecided.

From the table also, the majority of the respondents $28.91 \%$ and $33.59 \%$ strongly agreed and agreed respectively that SMEs in North Central Nigeria frequently operated in new market. $11.72 \%$ and $9.90 \%$ strongly disagreed and disagreed respectively, while $15.89 \%$ were undecided.

Table 10: Descriptive Statistics

Descriptive Statistics

\begin{tabular}{|l|l|l|l|l|l|}
\hline & $\mathrm{N}$ & Minimum & Maximum & Mean & Std. Deviation \\
\hline PSME & 384 & 1.00 & 5.00 & 3.3490 & 1.38364 \\
BM & 384 & 1.00 & 5.00 & 3.6797 & 1.29631 \\
HR & 384 & 1.00 & 5.00 & 3.4766 & 1.34590 \\
TC & 384 & 1.00 & 5.00 & 3.2057 & 1.47808 \\
CBE & 384 & 1.00 & 5.00 & 3.4219 & 1.36121 \\
CWS & 384 & 1.00 & 5.00 & 3.3620 & 1.45308 \\
ONR & 384 & 1.00 & 5.00 & 3.2682 & 1.46978 \\
Valid N (listwise) & 384 & & & & \\
\hline
\end{tabular}

Source SPSS version 20.00

The table 10 revealed the result of descriptive statistics, which indicated the mean and standard deviation as well as the minimum and maximum value of the variables. The mean value of performance of SMEs (PSME) is 3.34, business model (BM) is 3.67 , the mean value of held resources (HR) is 3.47 , the mean value of transactional cost (TC) is 3.20 , the mean value of contact with employees (CBE) is 3.42, the mean value of contact with suppliers (CWS) is 3.45 and the mean value of organizational environment (OR) is 3.426 , The table also recorded the standard deviation of the variables.

Table 11. Regression Analysis

Model Summary
\begin{tabular}{|l|l|l|l|l|}
\hline Model & $\mathrm{R}$ & R Square & $\begin{array}{l}\text { Adjusted } \\
\text { Square }\end{array}$ & $\begin{array}{l}\text { Std. Error of } \\
\text { the Estimate }\end{array}$ \\
\hline 1 & $.964^{\mathrm{a}}$ & .929 & .928 & .37039 \\
\hline
\end{tabular}

a. Predictors: (Constant), TC, BM, HR

ANOVA $^{\mathrm{a}}$

\begin{tabular}{|l|lr|l|l|l|l|}
\hline Model & $\begin{array}{l}\text { Sum } \\
\text { Squares }\end{array}$ & of & df & Mean Square & F & Sig. \\
\hline
\end{tabular}




\begin{tabular}{|ll|l|l|l|l|l|}
\hline \multirow{4}{*}{1} & Regression & 681.107 & 3 & 227.036 & 1654.893 & $.000^{\mathrm{b}}$ \\
& Residual & 52.132 & 380 & .137 & & \\
& Total & 733.240 & 383 & & & \\
\hline
\end{tabular}

a. Dependent Variable: PSME

b. Predictors: (Constant), TC, BM, HR

Coefficients $^{\mathrm{a}}$

\begin{tabular}{|ll|l|l|l|l|l|}
\hline \multicolumn{2}{|l|}{ Model } & \multicolumn{2}{|l|}{ Unstandardized Coefficients } & $\begin{array}{l}\text { Standardized } \\
\text { Coefficients }\end{array}$ & T & \multirow{2}{*}{ Sig. } \\
\cline { 3 - 5 } & B & Std. Error & Beta & & \\
\hline \multirow{2}{*}{1} & (Constant) & .034 & .062 & & .556 & .579 \\
& BM & .500 & .049 & .469 & 10.134 & .000 \\
& HR & -.113 & .061 & -.110 & -1.860 & .064 \\
& TC & .583 & .043 & .622 & 13.397 & .000 \\
\hline
\end{tabular}

a. Dependent Variable: PSME

Source: econometric output, 2021

Decision rule: $5 \%$

The model is fit and also business model has a positive and significant effect on the performance of SMEs in North Central Nigeria, held resources has a negative and insignificant effect on the performance of SMEs in North Central Nigeria while transactional cost has a positive and significant effect on the performance of SMEs in North Central Nigeria. These effects are significant since the P-values are less than 5\% and insignificant since the p-value is more than $5 \%$. Thus, the study concluded that business model has a positive and significant effect on the performance of SMEs in North Central Nigeria, held resources has a negative and insignificant effect on the performance of SMEs in North Central Nigeria while transactional cost has a positive and significant effect on the performance of SMEs in North Central Nigeria.

The $\mathrm{R}^{2}=0.92$ indicates that only $92 \%$ of variation on external relational capital can be used to explain the performance of SMEs in North Central Nigeria but $8 \%$ can be explained by other factors not noted in the regression model which is referred to as error term.

Table 12. Regression Analysis

Model Summary

\begin{tabular}{|l|l|l|l|l|}
\hline Model & $\mathrm{R}$ & R Square & $\begin{array}{l}\text { Adjusted R } \\
\text { Square }\end{array}$ & $\begin{array}{l}\text { Std. Error of } \\
\text { the Estimate }\end{array}$ \\
\hline 1 & $.954^{\mathrm{a}}$ & .911 & .910 & .41504 \\
\hline
\end{tabular}

a. Predictors: (Constant), OR, CBE, CWS

ANOVA $^{\mathrm{a}}$

\begin{tabular}{|c|c|c|c|c|c|}
\hline Model & $\begin{array}{ll}\text { Sum } & \text { of } \\
\text { Squares } & \end{array}$ & df & Mean Square & $\mathrm{F}$ & Sig. \\
\hline $\begin{array}{l}\text { Regression } \\
\text { Residual } \\
\text { Total }\end{array}$ & $\begin{array}{l}667.781 \\
65.459 \\
733.240\end{array}$ & $\begin{array}{l}3 \\
380 \\
383\end{array}$ & $\begin{array}{l}222.594 \\
.172\end{array}$ & 1292.201 & $.000^{\mathrm{b}}$ \\
\hline
\end{tabular}

a. Dependent Variable: PSME

b. Predictors: (Constant), OR, CBE, CWS

Coefficients $^{\mathrm{a}}$

\begin{tabular}{|ll|l|l|l|l|l|}
\hline \multicolumn{2}{|l|}{ Model } & \multicolumn{2}{l|}{ Unstandardized Coefficients } & $\begin{array}{l}\text { Standardized } \\
\text { Coefficients }\end{array}$ & T & \multirow{2}{*}{ Sig. } \\
\cline { 3 - 5 } \multicolumn{2}{l|l|}{} & $\mathrm{B}$ & Std. Error & Beta & & \\
\hline \multirow{2}{*}{1} & (Constant) & .273 & .060 & & 4.584 & .000 \\
& CBE & .226 & .071 & .223 & 3.188 & .002 \\
& CWS & .196 & .089 & .206 & 2.197 & .029 \\
& OR & .502 & .074 & .534 & 6.777 & .000 \\
\hline
\end{tabular}

a. Dependent Variable: PSME

Source: econometric output, 2021 


\section{Decision rule: $5 \%$}

The model is fit and also contact with employees has a positive and significant effect on the performance of SMEs in North Central Nigeria, contact with suppliers has a positive and significant effect on the performance of SMEs in North Central Nigeria while organizational environment has a positive and significant effect on the performance of SMEs in North Central Nigeria. These effects are significant since the P-values are less than $5 \%$. Thus, the study concluded that contact with employees has a positive and significant effect on the performance of SMEs in North Central Nigeria, contact with suppliers has a positive and significant effect on the performance of SMEs in North Central Nigeria while organizational environment has a positive and significant effect on the performance of SMEs in North Central Nigeria.

The $\mathrm{R}^{2}=0.91$ indicates that only $91 \%$ of variation on internal relational capital can be used to explain the performance of SMEs in North Central Nigeria but $9 \%$ can be explained by other factors not noted in the regression model which is referred to as error term.

\section{DISCUSSION OF FINDINGS}

The study found that relational capital has a positive and significant effect on the performance of SMEs in North Central Nigeria. This implies that internal relational capital and external relational capital has a positive and significant effect on the performance of SMEs in North Central Nigeria. Other findings were that business model has a positive and significant effect on the performance of SMEs in North Central Nigeria, held resources has a negative and insignificant effect on the performance of SMEs in North Central Nigeria while transactional cost has a positive and significant effect on the performance of SMEs in North Central Nigeria. The study also found that contact with employees has a positive and significant effect on the performance of SMEs in North Central Nigeria, contact with suppliers has a positive and significant effect on the performance of SMEs in North Central Nigeria while organizational environment has a positive and significant effect on the performance of SMEs in North Central Nigeria. The study is in line with the findings of Datta and De (2017) who found positive and significant effect relationship between the variables. The study is also in line with the production innovation theory by Hargadon and Sutton (1997) that states that continuous innovation is often related to occupying a "structural hole", that is, there should be no gap in the flow of information between subgroups in a larger network. Knowledge is often shared imperfectly through time, people, organizations and industries. The ideas that come up in a group could solve other groups' problems, but that can only happen if there are links that can go through the existing frontiers between solutions and problems.

\section{CONCLUSIONS AND RECOMMENDATIONS}

The study concluded that relational capital has a positive and significant effect on the performance of SMEs in North Central Nigeria. This implies that internal relational capital and external relational capital has a positive and significant effect on the performance of SMEs in North Central Nigeria. Other conclusions were that business model has a positive and significant effect on the performance of SMEs in North Central Nigeria, held resources has a negative and insignificant effect on the performance of SMEs in North Central Nigeria while transactional cost has a positive and significant effect on the performance of SMEs in North Central Nigeria.

The study also concluded that contact with employees has a positive and significant effect on the performance of SMEs in North Central Nigeria, contact with suppliers has a positive and significant effect on the performance of SMEs in North Central Nigeria while organizational environment has a positive and significant effect on the performance of SMEs in North Central Nigeria.

The study recommended that SMEs should continue to manage and nurture their relational capital in the North Central zone of Nigeria, as it appears to be more successful in increasing their performances. However, only one of the elements that comprised relational capital revealed an insignificant effect on SMEs performance, which is held resources. Therefore, SMEs should try and minimize these held resources so as to improve their relationship with suppliers.

\section{REFERENCES}

[1] Bronzetti, G., Mazzolta, R., Puntillo, P., Silvestri, A., \& Veltri, S. (2011) Intellectual capital reporting practices in the non-profit sector. Virtus Interpress: Ukraine,

[2] Brumbach, G. B., (2005) Some ideas, issues and predictions about performance management. Public personnel management, 387-402

[3] Chomiak-Orsa, I. (2013). Zarządzanie kapitałem relacyjnym w procesie wirtualizacji organizacji: podejście modelowe. Wrocław: Wydawnictwo Uniwersytetu Ekonomicznego we Wrocławiu.

[4] Dahou, K., \& Hacini, I., (2018) Effect of Human Capital Managementišen Firm Performance via Balanced Scorecard

[5] Datta, S. K., \& De, T., (2017) Role of Relational Capital and Firm Performance: Analysis of a Cluster of Bell-metal Enterprises in a Rural Region in West Bengal, India. Journal of Entrepren Organiz Manag 6: 204.

[6] Dundon, T., \& Wilkinson, A. (2018). HRM in small and medium-sized enterprises (SMEs). In Human Resource Management. Routledge.

[7] Edvinsson, L., \& Malone, M. S., (1997) Developing intellectual capital at Skandia, Long Range Planning 30(3) 266-373

[8] Fitz-enz, J., (2000). The ROI of human capital. New York, NY: Amacom.

[9] Gumel, B. I. (2017). Critical challenges facing small business enterprise in Nigeria: A literature review. International Journal of Scientific and Engineering Research, 8(8): 796-808

[10] Hargadon, A., \& Sutton, R. I. (1997) Technology brokering and innovation in a product development firm, Administrative Science Quarterly, 42(4), 716-49.

[11] Heide, J. B., \& John G., (1992) Do norms matter in marketing relationships? Journal of Marketing, 56, 2. HOWE J. (2006). The rise of crowdsourcing. Wired Magazine, 14.

[12] Hsu, Y. H., \& Fang, W. (2009). Intellectual capital and new product development performance: The mediating role of organisational learning capability. Technological Forecasting \& Social Change. 76, 664-677

[13] Huang, Y. C., \& Wu, Y. C., (2010) Intellectual capital and knowledge productivity: the 48(4): 580-599.

Taiwan biotech industry Manage. Decision.

[14] Ishaya, L. C., \& Abduljeleel, B. O., (2014) Capital structure and profitability of Nigerian Quoted Firms: The Agency Cost Theory Perspective. American International Journal of Social Science, 3(1)

[15] Martín de Castro, G., Delgado-Verde, M., López-Saez, P., \& Navas-López, J. E., (2011) Towards 'an intellectual capital- based view of the firm': origins and nature, Journal of Business Ethics, 98, 649-62.SEP 
[16] Mekwunye U. (2018). Nigeria: Small and medium scale enterprises in Nigeria. An overview of initial set up https://www.mondaq.com/nigeria/directors-and-officers/757432

[17] Mihaela B. T., (2012) Capital Structure and Firm Performance. Economy transdisciplinary Cognition, 15(2)

[18] Oforegbunam, T. E., \& Okorafor, G. F. (2010). Effects of human capital development on the performance of Small and Medium Scaled Enterprises in the Southeastern Region of Nigeria. Journal of Sustainable Development in Africa, 12 (8)

[19] Ogundipe, S. E., (2012) Business relational capital and firm performance in south western Nigerian small-scale enterprise clusters. European Journal of Business and Management 4 (17)

[20] Pedro, F. D., Ricardo, V. C., \& Carlos, F. F., (2013) Product innovation and relational capital: evidence from Portugal. Electronic Journal of Knowledge Management 11(4)

[21] Republic of Kenya (RoK). Economic Survey (2005). Nairobi Kenya: Government Printers.

[22] Roos, G., Bainbridge, A. Y., \& Jacobsen, K., (2001) Intellectual capital analysis as a strategic tool, Strategy \& Leadership, 29 (4) 21-26.

[23] Sveiby, K., (1997) The New organisational wealth: Managing and measuring knowledge based assets. Berrett-Kohler, San Francisco, CA.

[24] Udechukwu, F. N., (2003). Survey of small and medium scale industries and their potentials in Nigeria. In SMIEIS seminar by the CBN.
[25] Wong, K. Y., \& Aspinwall, E., (2004) "Characterizing knowledge management in the small business environment", J. Knowledge Manage., 8(3): 44-61.

[26] Zeitun, R., \& Tian, G. G. (2007) Capital structure and corporate performance: evidence from Jordan. Australasian Accounting, Business and Finance Journal, 1(4)

\section{AUTHORS}

First Author - UDOH, Francis Sylvanus, Department of Business Administration, Nasarawa State University Keffi slyosly79@gmail.com

Second Author - BUKOYE, Josiah Ayoola, Department of Business Administration, Nile University of Nigeria josiahbukoye@gmail.com

Third Author - YAHAYA, Kabiru Maigari, Department of Business Administration, Nasarawa State University Keffi kabirmaigari@gmail.com 